\title{
Long-term clinical outcomes of hematopoietic cell transplantation for intermediate-to-poor-risk acute myeloid leukemia during first remission according to available donor types
}

\author{
Jae-Ho Yoon ${ }^{1}$, Hee-Je Kim ${ }^{1}$, Sung-Soo Park ${ }^{1}$, Young-Woo Jeon ${ }^{1}$, Sung-Eun Lee ${ }^{1}$, \\ Byung-Sik Cho ${ }^{1}$, Ki-Seong Eom ${ }^{1}$, Yoo-Jin Kim ${ }^{1}$, Seok Lee ${ }^{1}$, Chang-Ki Min ${ }^{1}$, Seok- \\ Goo Cho ${ }^{1}$, Dong-Wook Kim ${ }^{1}$, Jong-Wook Lee ${ }^{1}$ and Woo-Sung Min ${ }^{1}$ \\ ${ }^{1}$ Department of Hematology, Catholic Blood and Marrow Transplantation Center, Leukemia Research Institute, Seoul St. \\ Mary's Hospital, College of Medicine, The Catholic University of Korea, Seoul, Korea \\ Correspondence to: Hee-Je Kim, email: cumckim@catholic.ac.kr \\ Keywords: acute myeloid leukemia; allogeneic hematopoietic cell transplantation; autologous hematopoietic cell transplanta- \\ tion; familial mismatched hematopoietic cell transplantation \\ Received: March 29, $2016 \quad$ Accepted: January 03, $2017 \quad$ Published: February 11, 2017
}

Copyright: Yoon et al. This is an open-access article distributed under the terms of the Creative Commons Attribution License 3.0 (CC BY 3.0), which permits unrestricted use, distribution, and reproduction in any medium, provided the original author and source are credited.

\section{ABSTRACT}

Standard therapy for acute myeloid leukemia (AML) consists of hematopoietic cell transplantation (HCT) including autologous-HCT (AUTO) and allogeneic-HCT from a matched-sibling donor (MSD) or well-matched unrelated donor (WM-URD). When a conventional donor is not available, HCT from a partially-matched (PM)-URD or familial-mismatched donor (FMMD) is typically considered. We analyzed 561 patients with intermediate to poor-risk molecular cytogenetics who underwent transplant from 2002 to 2013 in their first remission. Engraftment was successful in all donor types except five patients who died in aplasia. Disease-free survival (DFS) at 5 years was $61.4 \%$ for MSD, $62.1 \%$ for WM-URD, $65.3 \%$ for FMMD, $44.7 \%$ for AUTO and $36.8 \%$ for PM-URD. AUTO showed the highest relapse rate (51.0\%) compared to MSD $(23.5 \%)$ and FMMD (18.5\%), but showed the lowest 5-year non-relapse mortality (NRM) rate (3.8\%). PM-URD showed the highest NRM (29.3\%) with more instances of acute graft-vs.-host disease (GVHD) with grade $\geq$ III $(29.3 \%)$, compared to MSD (15.6\%) and FMMD (15.7\%). In a poor-risk subgroup, the 5-year DFS for FMMD and MSD was $59.8 \%$ and $46.7 \%$, respectively, while for AUTO and PM-URD it was $12.6 \%$ and $0.0 \%$, respectively, which was caused by a high relapse rate $(87.1 \%$ in AUTO, $83.3 \%$ in PMURD). In the intermediate-risk subgroup, the 5-year DFS of AUTO (53.9\%) was not different from the conventional donors in multivariate analysis, presenting a low NRM rate $(5.1 \%)$. FMMD should be considered prior to PM-URD in intermediate-to-poorrisk AML and GVHD prophylaxis should be intensified when PM-URD is needed. AUTO might be considered for selected patients in the intermediate-risk group.

\section{INTRODUCTION}

Standard therapy for acute myeloid leukemia (AML) consists of several hematopoietic cell transplantation (HCT) strategies including autologous (AUTO)HCT, allogeneic-HCT from a matched-sibling donor (MSD), or well-matched unrelated donor (WM-URD) transplantation. Although many reports show positive results in the favorable-risk group [1-5] and in selected patients with non-favorable karyotypes [6-10], the role of AUTO-HCT still remains unclear, and the procedure fell out of fashion in clinical trials. In contrast, allogeneic-HCT is regarded as a curative option for adult AML patients in their first complete remission (CR1), especially in the intermediate- and poor-risk groups, which showed lower relapse rates showing graft-versus-leukemia (GVL) effect 
compared to AUTO-HCT or chemotherapy alone [11-13]. However, only $30 \%$ of patients have human leukocyte antigen (HLA)-identical sibling donors available [14, 15], and therapy-related mortality caused by complications from infections or acute/chronic graft-versus-host disease (GVHD) is still an important challenge in allogeneicHCT [16]. When searching for HCT donors, if a MSD is not available, a WM-URD is another standard choice since the survival outcomes are comparable due to the development of immunosuppressive agents $[17,18]$. When neither standard HCT donors are available, alternative donor types, such as a partially-matched unrelated donor (PM-URD) or a familial mismatched/haploidentical transplantation (FMMT), are now being considered [19].

Previous data showed that HLA-mismatch was associated with more transplantation-related complications and poorer survival outcome caused by higher rates of graft failure and higher-grade GVHD [20-22] . However, many recent studies have shown that the outcomes of FMMTs have been significantly improved by optimization of pre-conditioning regimens and the development of modalities for immunosuppression to overcome major HLA barriers [23-27], while PM-URD is still controversial as a viable alternative [18, 28, 29]. In addition, HLAmismatch can potentially induce natural killer (NK)-cell alloreactivity, which may reduce relapse rates of AML $[30,31]$. For FMMT specifically, we can expect prompt donor availability, preferred graft control, and a timely application of repeated donations, which may be large advantages to poor-risk AML patients who are in urgent need of allogeneic-HCT [14, 15]. Despite the positive expectations for FMMT, few prospective studies have analyzed survival outcomes compared to standard donor types, and true randomized studies cannot be conducted for ethical reasons.

We have previously analyzed the clinical outcomes of FMMT compared to WM-URD and PM-URD in a pilot study with a small number of patients and a short followup duration [19]. In the current study, we analyzed the long-term HCT outcomes of several donor types, including AUTO-HCT, MSD, WM-URD, PM-URD and FMMT, in intermediate- to poor-risk AML patients in CR1.

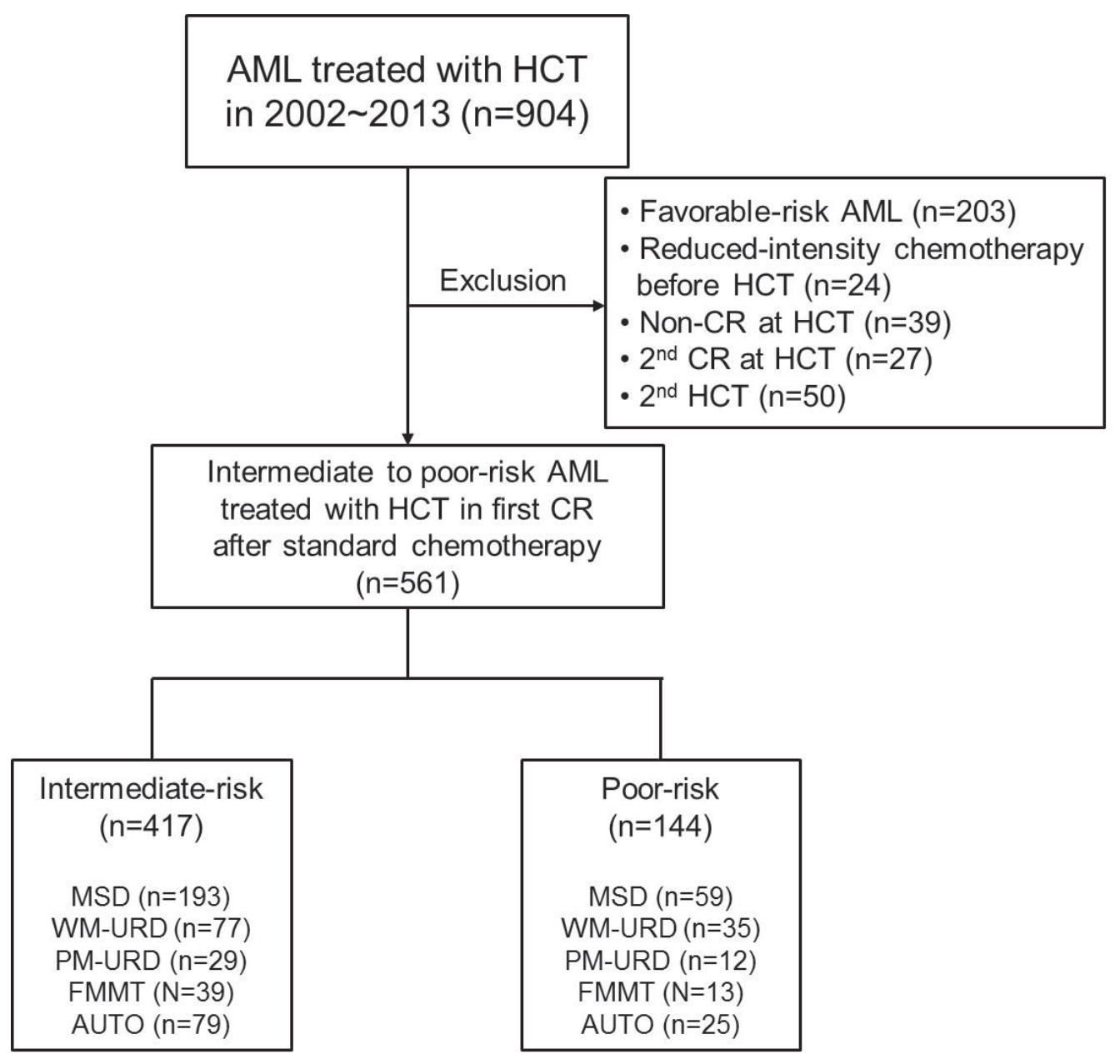

Figure 1: Consort diagram of analyzed patients in the current study. Abbreviation: AML, Acute myeloid leukemia; HCT, hematopoietic cell transplantation; CR, complete remission; MSD, matched sibling donor; WM-URD, well matched unrelated donor; PMURD, partially matched unrelated donor; FMMT, familial mismatched transplantation; AUTO, autologous HCT 
Table 1: Baseline characteristics of the entire patients.

\begin{tabular}{|c|c|}
\hline & N (Total 561 patients) \\
\hline Age, median (range) & 40.0 years old $(16-68)$ \\
\hline Gender, male $(\%)$ & $295(52.5 \%)$ \\
\hline Leukocyte $\left(\times 10^{9} / \mathrm{L}\right)$, median (range) & $11.8(0.5-835.0)$ \\
\hline Platelet $\left(\mathrm{x} 10^{9} / \mathrm{L}\right)$, median (range) & $54.5(5.0-882.0)$ \\
\hline PB blast (\%), median (range) & $42.0(0-98)$ \\
\hline Diagnosis to HCT, median (range) & 5.5 months $(3.0-11.5)$ \\
\hline$<7$ months & $417(74.3 \%)$ \\
\hline$\geq 7$ months & $144(25.7 \%)$ \\
\hline \multicolumn{2}{|l|}{ WHO classification } \\
\hline \multicolumn{2}{|l|}{ Recurrent genetic abnormality } \\
\hline $\mathrm{t}(8 ; 21)(\mathrm{q} 22 ; \mathrm{q} 22) / \operatorname{inv}(16)(\mathrm{p} 13.1 \mathrm{q} 22)$ & $22(3.9 \%) / 8(1.4 \%)$ \\
\hline $\mathrm{t}(9 ; 11)(\mathrm{p} 22 ; \mathrm{q} 23)$ & $12(2.1 \%)$ \\
\hline $\mathrm{t}(6 ; 9)(\mathrm{p} 23 ; \mathrm{q} 34) / \operatorname{inv}(3)(\mathrm{q} 21 \mathrm{q} 26 . .2)$ & $9(1.6 \%) / 4(0.7 \%)$ \\
\hline AML MRC & $58(10.4 \%)$ \\
\hline Therapy-related AML & $5(0.9 \%)$ \\
\hline AML M0 & $22(3.9 \%)$ \\
\hline AML M1 & $127(22.6 \%)$ \\
\hline AML M2 & $155(27.6 \%)$ \\
\hline AML M4 & $60(10.7 \%)$ \\
\hline AML M5 & $49(8 . \%)$ \\
\hline AML M6 & $22(3.9 \%)$ \\
\hline AML M7 & $7(1.2 \%)$ \\
\hline Acute panmyelosis with myelofibrosis & $1(0.2 \%)$ \\
\hline \multicolumn{2}{|l|}{ Molecular cytogenetics (NCCN) } \\
\hline \multicolumn{2}{|l|}{ Intermediate-risk $(n=417)$} \\
\hline CN-AML (molecular data unavailable) & $137(24.4 \%)$ \\
\hline FLT3-ITD(-) CN-AML & $120(21.4 \%)$ \\
\hline c-kit positive CBF-AML & $30(5.3 \%)$ \\
\hline Others & $130(23.2 \%)$ \\
\hline \multicolumn{2}{|l|}{ Poor-risk $(\mathrm{n}=144)$} \\
\hline FLT3-ITD $(+)$ CN-AML & $35(6.2 \%)$ \\
\hline Others & $109(19.4 \%)$ \\
\hline \multicolumn{2}{|l|}{ Induction } \\
\hline Idarubicin/BHAC $3+7$ & $338(60.2 \%)$ \\
\hline Idarubicin/ARA-C 3+7 & $223(39.8 \%)$ \\
\hline \multicolumn{2}{|l|}{ Post-remission therapy } \\
\hline Autologous HCT & $104(18.5 \%)$ \\
\hline \multicolumn{2}{|l|}{ Allogeneic HCT } \\
\hline Matched sibling donor & $252(44.9 \%)$ \\
\hline Unrelated donor & $153(27.3 \%)$ \\
\hline Familial mismatched donor & $52(9.3 \%)$ \\
\hline \multicolumn{2}{|l|}{ HCT conditioning regimen } \\
\hline \multicolumn{2}{|l|}{$\operatorname{MAC}(n=463)$} \\
\hline Cyclophosphamide/TBI 1320 cGy & $282(50.3 \%)$ \\
\hline Busulfan/TBI 1320 cGy & $16(2.9 \%)$ \\
\hline Busulfan/Cyclophosphamide & $44(7.8 \%)$ \\
\hline Cytarabine/Melphalan/TBI $1200 \mathrm{cGy}$ & $121(21.6 \%)$ \\
\hline \multicolumn{2}{|l|}{$\operatorname{RIC}(\mathrm{n}=98)$} \\
\hline Busulfan/Fludarabine/TBI 400 cGy & $46(8.2 \%)$ \\
\hline Busulfan/Fludarabine/TBI 800 cGy & $52(9.3 \%)$ \\
\hline \multicolumn{2}{|l|}{ HCT source } \\
\hline BM & $225(40.1 \%)$ \\
\hline PB & $324(57.8 \%)$ \\
\hline $\mathrm{BM}+\mathrm{PB}$ & $12(2.1 \%)$ \\
\hline
\end{tabular}

Abbreviation: $\mathrm{PB}$, peripheral blood; BM bone marrow; AML, acute myeloid leukemia; MRC, myelodysplasia-related change; CN, cytogenetically normal; CBF, core-binding factor positive; BHAC, N4-behenoyl-1- $\beta$-D-arabinofuranosyl cytosine; ARA-C, cytosine arabinoside; HCT, hematopoietic cell transplantation; MAC, myeloablative conditioning; RIC, Reduced intensity conditioning; TBI, total body irradiation; 


\section{RESULTS}

\section{Baseline characteristics}

A consort diagram of the finally-selected 561 patients with intermediate- to poor-risk molecular cytogenetics is presented in Figure 1. All 561 patients underwent $\mathrm{HCT}$ in the first remission after intensive chemotherapy and the baseline characteristics are described in Table 1. Among them, there were 417 patients in the intermediate-risk group and 144 patients in the poor-risk group (Figure 1). The median age was 40 years old (range, 16-68 years old) and the median time to HCT was 5.5 months (range, 3.0-11.5 months). In 144 (25.7\%) patients, the time to HCT exceeded 7 months. Among them, 68 patients had a slight delay (within 7.5 months) mainly due to the lack of transplantation facilities, 19 patients underwent numerous chemotherapy

A

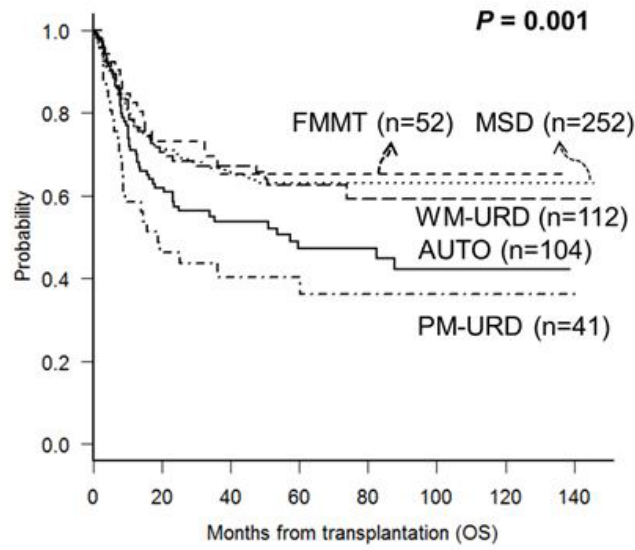

C

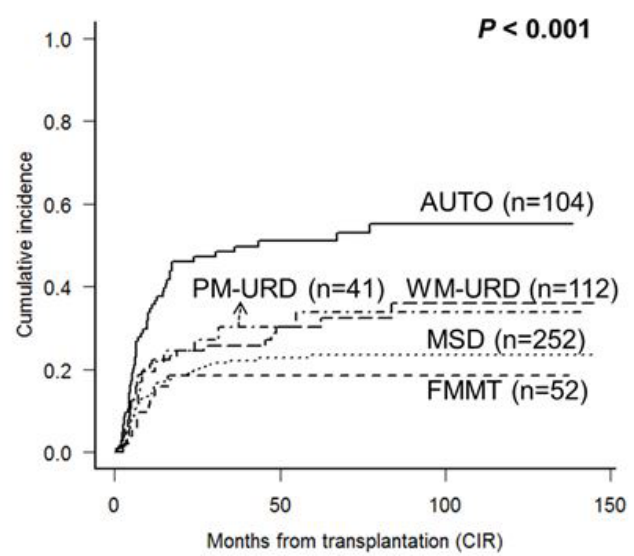

cycles ( $>3$ cycles with 2 month-interval) due to a delayed first CR, 10 patients had a delayed donor search, and 47 patients suffered from either delayed neutrophil recovery or infectious complications after prior chemotherapy. Among patients with core-binding factor-positive AML, $c$-kit mutations were identified in 30 patients who were then included in the intermediate-risk group. Among the 356 cytogenetically normal (CN)-AML patients, 64 $(18.0 \%)$ with an isolated NPM1 mutation were classified into the favorable-risk group and excluded initially, while $137(38.5 \%)$ patients without available molecular data and 120 (33.7\%) NPM1-negative/FLT3-ITD-negative patients were classified into the intermediate-risk group. Thirtyfive CN-AML patients with FLT3-ITD mutations (10.0\%) were classified into the poor-risk group. For pre-transplant chemotherapy, $60.2 \%$ of patients were treated with an $\mathrm{N}^{4}$-behenoyl-1- $\beta$-D-arabinofuranosyl cytosine- (BHAC) based regimen and $39.8 \%$ of patients were treated with a cytosine arabinoside- (ARA-C) based regimen. AUTO was performed in 104 (18.5\%) patients, MSD-HCT in 252

B

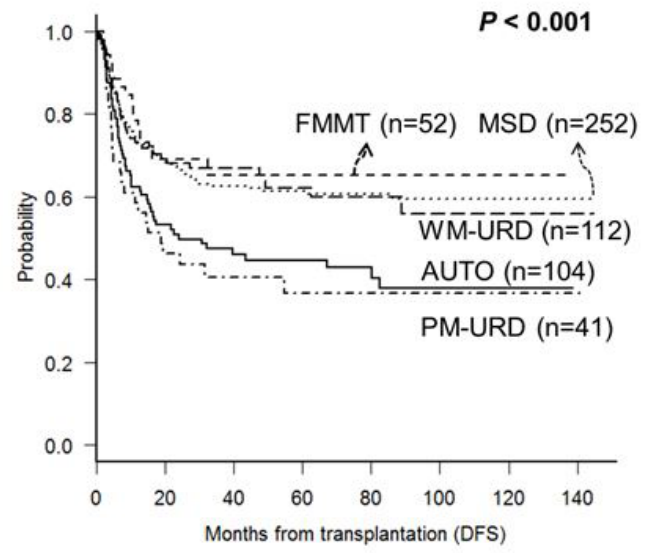

D

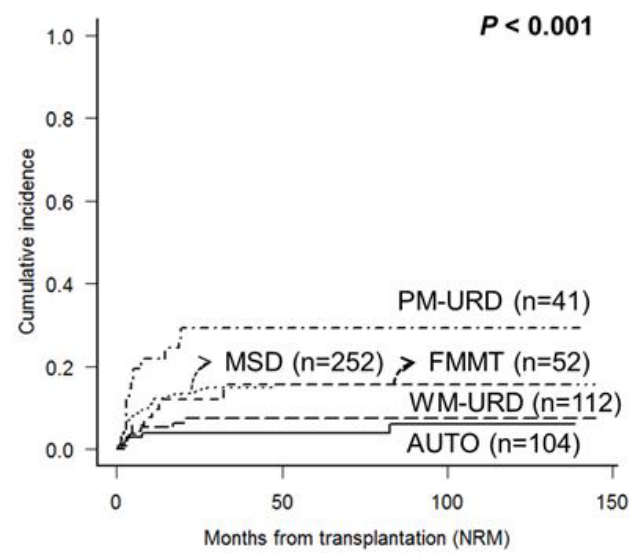

Figure 2: Treatment outcomes of total 561 patients according to the transplantation donor sources. A. OS. B. DFS. C. CIR. D. NRM. 
(44.9\%) patients, URD-HCT in 153 (27.3\%) patients, and FMMT in $52(9.3 \%)$ patients. Among the patients treated with URD-HCT, 112 patients received stem cells from WM-URD and 41 from PM-URD. Almost half of the patients $(50.3 \%)$ were treated with cyclophosphamide plus 1320 cGy of total body irradiation (TBI), while a reducedintensity conditioning (RIC) regimen was used in $8.2 \%$ of patients, and $9.3 \%$ of patients were treated with an FMMT regimen.

Pre- and post-HCT parameters are presented in Table 2 according to HCT donor type. Between the subgroups, there were more female patients in the MSD subgroup, and the MSD and WM-URD subgroups had more patients who underwent HCT within 7 months. Blood cell and blast counts, as well as the molecular cytogenetic risk

A

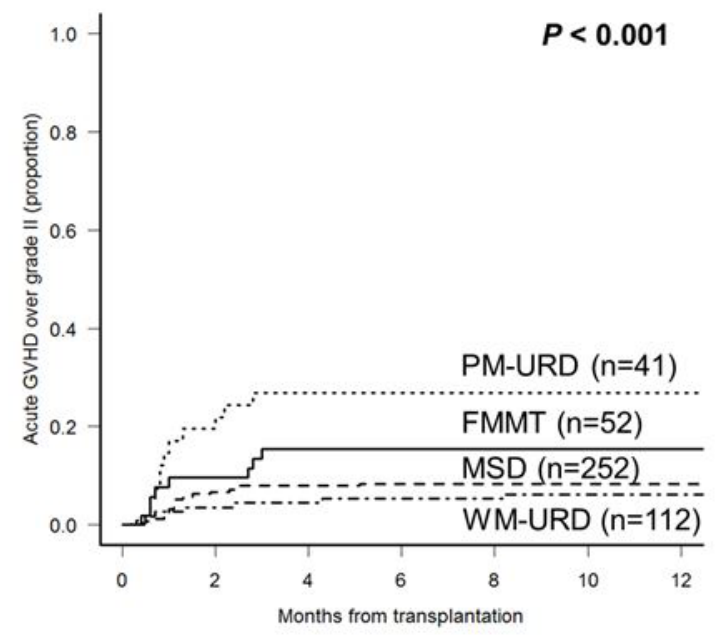

$\mathrm{C}$

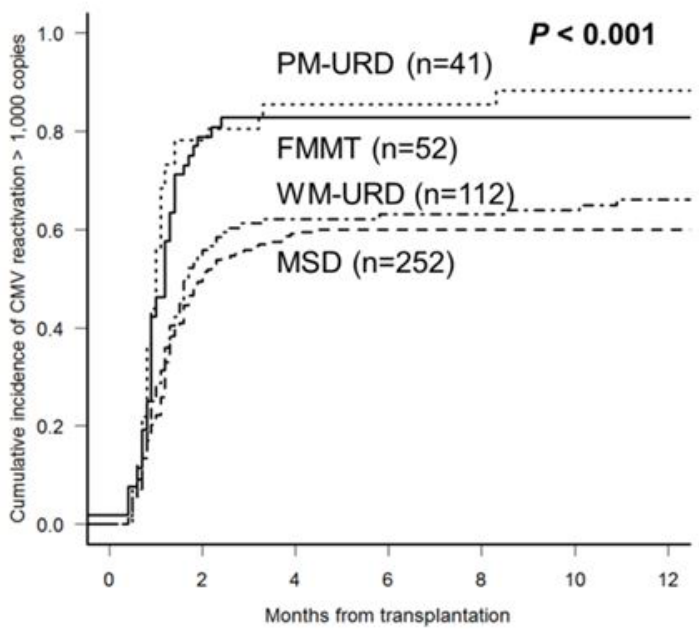

groups were not significantly different between the 5 subgroups. FMMT and AUTO were conducted using the same HCT conditioning regimen, while MSD- and URDHCT were conducted using variable regimens including myeloablative conditioning (MAC) and RIC. The MAC regimen was used in $88.9 \%$ of cases for MSD, $85.7 \%$ for WM-URD, and $95.1 \%$ for PM-URD. Among the MAC regimens, TBI-based conditioning regimens were used more often with MSD-HCT compared to URD-HCT $(92.9 \% v s .79 .3 \%, p=0.001)$. BM was more often used for the stem cell source in MSD-HCT compared to URD-HCT (71.1\% vs. 36.6\%, $p<0.001)$, while all of the FMMT and AUTO procedures were conducted with $\mathrm{PB}$ as the stem cell source. The CD34+ stem-cell dose was significantly higher in FMMT, while the CD3+ dose was significantly

B

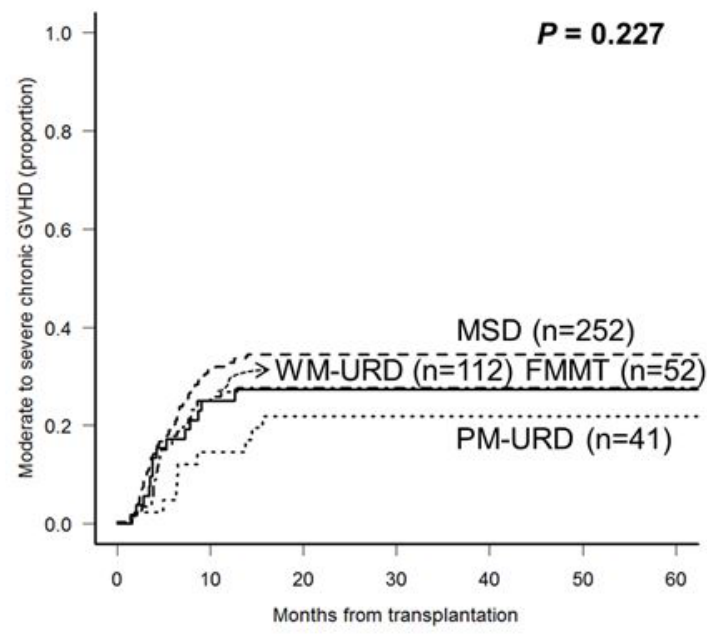

D

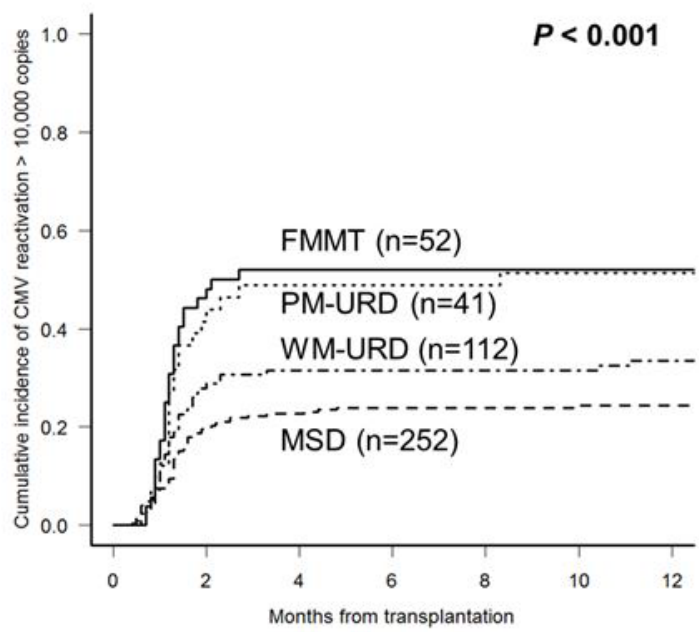

Figure 3: Cumulative incidence of post-HCT complications according to the donor sources. A. Acute GVHD over grade II. B. Moderate to severe chronic GVHD. C. CMV reactivation over 1,000 copies $/ \mathrm{mL}$. D. CMV reactivation over 10,000 copies $/ \mathrm{mL}$. 
lower in MSD-HCT compared to the other donor types.

\section{Clinical outcomes}

Engraftment was successful in all patients, except for 5 patients who died either from aplasia due to infectious complications or from sudden cardiac death. The median time to neutrophil-count recovery was 1 day faster in FMMT (11 days, range: 10-17) compared to AUTO (12 days, range: 7-78), MSD (12 days, 2-30), WM-URD (12 days, range: 6-29), and PM-URD (12 days, range: $10-21)$. The median time to platelet-count recovery was longer in MSD (15 days, range: 0-44) and PM-URD (13 days, range: 5-45) compared to FMMT (12 days, range: 0-21), AUTO (11 days, range: 0-123), and WMURD (12 days, range: 0-50). However, after adjusting for

A

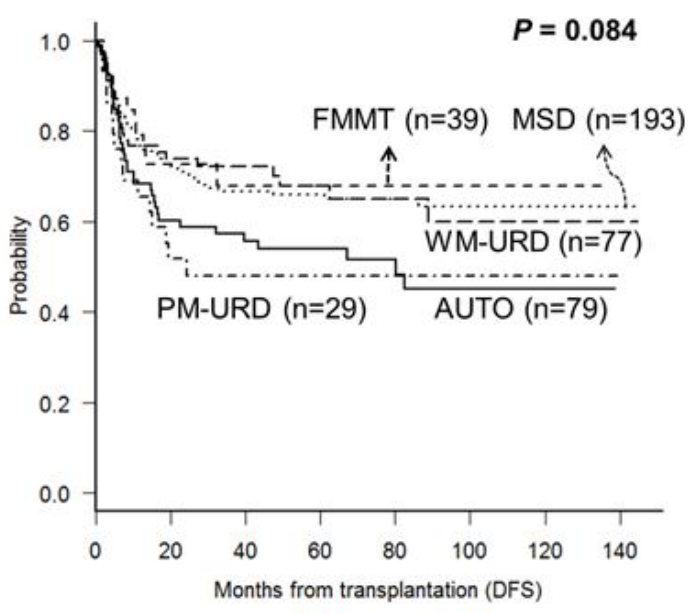

C

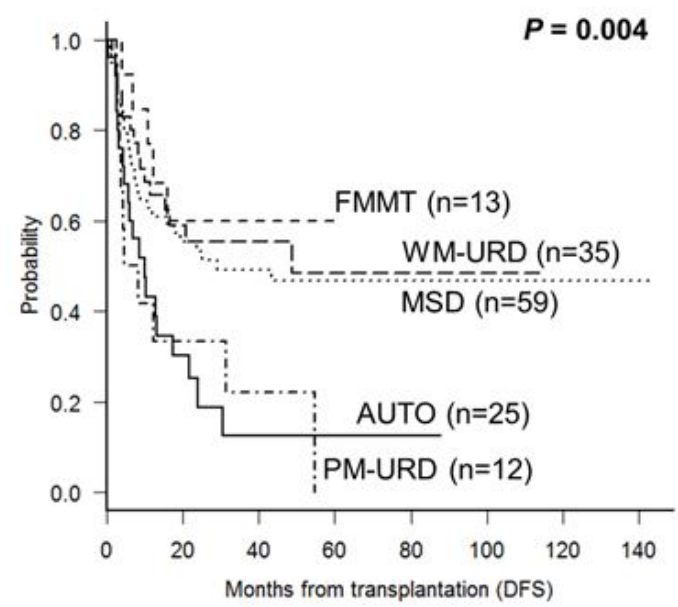

pre-conditioning intensity and stem cell sources, recovery times were not significantly different between the donor types. Our data shows that ABO mismatch, sex mismatch, certain HLA locus mismatches between the donor and recipient, and stem cell source were not influential for either survival outcome or the incidence rate of acute and chronic GVHD. At the time of data analysis, 218 of the 561 patients had died, with 148 from leukemia relapse and 70 from other causes. The most common cause of death was pneumonia $(n=22)$ from variable causes invasive aspergillosis $(n=6)$, Pneumocystis jirovecii pneumonia $(n=4)$, CMV pneumonia $(n=2)$, idiopathic $(n=10)$ - followed by acute gut GVHD $(n=11)$, venoocclusive disease $(n=7)$, sepsis $(n=6)$, acute hepatic GVHD $(n=5)$, chronic lung GVHD $(n=5)$, thrombotic microangiopathy $(n=4)$, and hemorrhagic cystitis $(n=$ $4)$, acute renal failure $(n=2)$, hepatitis B reactivation $(n=$

B

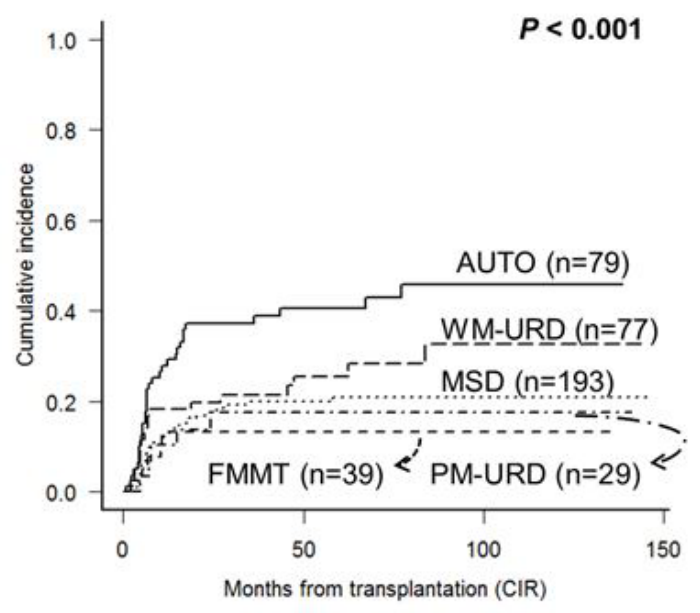

D

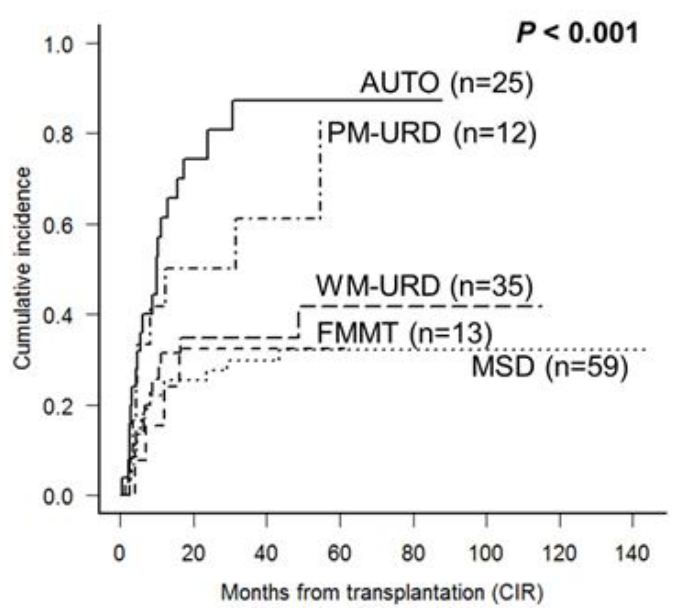

Figure 4: DFS and CIR rates according to the transplantation donor sources in the subgroup analysis. A. \& B. Intermediate-risk subgroup. C. \& D. Poor-risk subgroup. 
Table 2: Baseline characteristics of AML patients who achieved CR after standard chemotherapy.

\begin{tabular}{|c|c|c|c|c|c|c|}
\hline & $\begin{array}{l}\text { MSD } \\
(n=252)\end{array}$ & $\begin{array}{l}\text { WM-URD } \\
(\mathrm{n}=112)\end{array}$ & $\begin{array}{l}\text { PM-URD } \\
(n=41)\end{array}$ & $\begin{array}{l}\text { FMMT } \\
(\mathrm{n}=52)\end{array}$ & $\begin{array}{l}\text { AUTO } \\
(n=104)\end{array}$ & $p$ \\
\hline Age, median (range) & $41.0(16-68)$ & $37.0(16-68)$ & $42.0(16-60)$ & $41.0(16-64)$ & $39.0(16-67)$ & 0.158 \\
\hline Gender, male $(\%)$ & $112(44.4 \%)$ & $70(62.5 \%)$ & $24(58.5 \%)$ & $30(57.7 \%)$ & $59(56.7 \%)$ & $0.011 *$ \\
\hline Leukocyte $\left(\times 10^{9} / \mathrm{L}\right)$ & $12.4(0.5-376.2)$ & $12.7(1.2-835.0)$ & $11.6(0.9-123.9)$ & $11.1(0.8-395.9)$ & $11.5(0.9-308.4)$ & 0.759 \\
\hline Hemoglobin (g/dL) & $8.6(3.5-16.8)$ & $9.0(2.0-14.8)$ & $8.9(3.5-14.7)$ & $9.3(5.3-16.1)$ & $8.6(4.7-13.4)$ & 0.386 \\
\hline Platelet $\left(\times 10^{9} / \mathrm{L}\right)$ & $56.0(5.0-408.0)$ & $56.0(5.0-272.0)$ & $53.0(9.0-682.0)$ & $55.0(5.0-629.0)$ & $42.0(5.0-491.0)$ & 0.129 \\
\hline PB blast $(\%)$ & $45.5(0-98)$ & $32.0(0-98)$ & $42.0(0-98)$ & $47.5(0-94)$ & $40.5(0-98)$ & 0.369 \\
\hline BM blast $(\%)$ & $84.0(6-99)$ & $81.5(20-99)$ & $85.0(20-98)$ & $87.5(20-98)$ & $84.5(16-99)$ & 0.749 \\
\hline \multicolumn{7}{|l|}{ Diagnosis to HCT } \\
\hline$<7$ months & $224(88.9 \%)$ & $79(70.5 \%)$ & $24(58.5 \%)$ & $33(63.5 \%)$ & $57(54.8 \%)$ & $<0.001 *$ \\
\hline$\geq 7$ months & $28(11.1 \%)$ & $33(29.5 \%)$ & $17(41.5 \%)$ & $19(36.5 \%)$ & $47(45.2 \%)$ & \\
\hline \multicolumn{7}{|l|}{ Molecular Cytogenetics } \\
\hline Intermediate $(n=417)$ & $193(76.6 \%)$ & $77(68.8 \%)$ & $29(70.7 \%)$ & $39(75.0 \%)$ & $79(76.0 \%)$ & 0.569 \\
\hline CN-AML & $117(46.4 \%)$ & $38(33.9 \%)$ & $17(41.5 \%)$ & $22(42.3 \%)$ & $63(60.6 \%)$ & \\
\hline$c-k i t(+) \mathrm{CBF}-\mathrm{AML}$ & $16(6.4 \%)$ & $5(4.5 \%)$ & $2(4.8 \%)$ & $5(9.6 \%)$ & $2(1.9 \%)$ & \\
\hline Others & $60(23.8 \%)$ & $34(30.3 \%)$ & $10(24.4 \%)$ & $12(23.1 \%)$ & $14(13.4 \%)$ & \\
\hline Poor-risk $(n=144)$ & $59(23.4 \%)$ & $35(31.2 \%)$ & $12(29.3 \%)$ & $13(25.0 \%)$ & $25(24.0 \%)$ & 0.569 \\
\hline FLT3(+) CN-AML & $19(7.5 \%)$ & $10(8.9 \%)$ & $0(0.0 \%)$ & $3(5.8 \%)$ & $3(2.9 \%)$ & \\
\hline Others & $40(15.9 \%)$ & $25(22.3 \%)$ & $12(29.3 \%)$ & $10(19.2 \%)$ & $22(21.1 \%)$ & \\
\hline \multicolumn{7}{|l|}{ Induction } \\
\hline IDA/BHAC 3+7 & $153(60.7 \%)$ & $65(58.0 \%)$ & $28(68.3 \%)$ & $18(34.6 \%)$ & $74(71.2 \%)$ & $<0.001 *$ \\
\hline IDA/ARA-C 3+7 & $99(39.3 \%)$ & $47(42.0 \%)$ & $13(31.7 \%)$ & $34(65.4 \%)$ & $30(28.8 \%)$ & \\
\hline \multicolumn{7}{|l|}{ Conditioning regimen } \\
\hline \multicolumn{7}{|l|}{$\mathrm{TBI} \geq 800 \mathrm{cGy}(\mathrm{n}=463)$} \\
\hline CY/TBI 1320 cGy & $192(76.2 \%)$ & $65(58.1 \%)$ & $25(60.9 \%)$ & 0 & 0 & $0.001 * \dagger$ \\
\hline BU/TBI $1320 \mathrm{cGy}$ & $13(5.2 \%)$ & $2(1.8 \%)$ & $1(2.4 \%)$ & 0 & 0 & $0.273^{\dagger}$ \\
\hline TAM $1200 \mathrm{cGy}$ & $3(1.2 \%)$ & $8(7.1 \%)$ & $6(14.6 \%)$ & 0 & $104(100 \%)$ & $0.001 *$ \\
\hline BU/FLU/TBI 800cGy & 0 & 0 & 0 & $52(100 \%)$ & 0 & NA \\
\hline \multicolumn{7}{|l|}{$\mathrm{TBI}<800 \mathrm{cGy}(\mathrm{n}=98)$} \\
\hline $\mathrm{BU} / \mathrm{CY}$ & $16(6.3 \%)$ & $21(18.8 \%)$ & $7(17.1 \%)$ & 0 & 0 & $0.001 *$ \\
\hline BU/FLU/TBI 400cGy & $28(11.1 \%)$ & $16(14.3 \%)$ & $2(4.9 \%)$ & 0 & 0 & $0.262^{\dagger}$ \\
\hline \multicolumn{7}{|l|}{ HCT source } \\
\hline $\mathrm{BM}$ & $179(71.1 \%)$ & $39(34.8 \%)$ & $17(41.5 \%)$ & $0(0.0 \%)$ & $0(0.0 \%)$ & $<0.001 * \dagger$ \\
\hline $\mathrm{PB}$ & $69(27.4 \%)$ & $73(65.2 \%)$ & $24(58.5 \%)$ & $52(100 \%)$ & $96(92.3 \%)$ & \\
\hline $\mathrm{BM}+\mathrm{PB}$ & $4(1.5 \%)$ & $0(0.0 \%)$ & $0(0.0 \%)$ & $0(0.0 \%)$ & $8(7.7 \%)$ & \\
\hline CD34+ stem cells & $\begin{array}{l}3.26 \\
(0.47-49.00)\end{array}$ & $\begin{array}{l}4.7 \\
(0.17-27.39)\end{array}$ & $\begin{array}{l}4.7 \\
(0.68-34.44)\end{array}$ & $\begin{array}{l}6.34 \\
(0.63-17.1)\end{array}$ & $\begin{array}{l}3.76 \\
(0.10-24.87)\end{array}$ & $<0.001 *$ \\
\hline CD3+ stem cells & $\begin{array}{l}49.43 \\
(0.6-986.1)\end{array}$ & $\begin{array}{l}244.7 \\
(1.4-854.2)\end{array}$ & $\begin{array}{l}254.2 \\
(3.4-666.9)\end{array}$ & $\begin{array}{l}408.3 \\
(3.9-937.2)\end{array}$ & $\begin{array}{l}310 \\
(75.0-774.2)\end{array}$ & $<0.001^{*}$ \\
\hline
\end{tabular}

Subgroup was made according to the HCT donor source.

$\dagger p$-value analyzed between the first three groups except for FMMT and AUTO.

$* p<0.005$

Abbreviation: PB, peripheral blood; BM bone marrow; HCT, hematopoietic cell transplantation; CN, cytogenetically normal; $\mathrm{CBF}$, core-binding factor positive; BHAC, N4-behenoyl-1- $\beta$-D-arabinofuranosyl cytosine; ARA-C, cytosine arabinoside; TBI, total body irradiation; CY, cyclophosphamide; BU, busulfan; TAM, TBI plus ARA-C plus melphalan; FLU, fludarabine;

$2)$, sudden cardiac death $(n=1)$, and lymphoma $(n=1)$. After a median follow-up duration of 58.7 months (range: 9.6-150.6), the 5-year overall survival (OS) of MSD, WM-URD, and FMMT was $63.1 \%, 63.9 \%$, and $65.1 \%$, respectively, while the rates for AUTO and PM-URD, $47.2 \%$ and $40.3 \%$, respectively, were significantly inferior (Figure 2A). The disease-free survival (DFS) rate at 5 years was $61.4 \%$ for MSD, $62.1 \%$ for WM-URD, $65.3 \%$ for FMMT, $44.7 \%$ for AUTO, and $36.8 \%$ for PM-URD (Figure 2B). The 5-year cumulative incidence of relapse (CIR) rate was highest in AUTO (51.0\%), followed by
PM-URD (33.9\%), WM-URD (30.3\%), MSD (23.5\%), and FMMT (18.5\%) (Figure 2C). In contrast, the lowest 5-year non-relapse mortality (NRM) rate was identified in AUTO (3.8\%), followed by WM-URD (7.4\%), FMMT (15.7\%), and MSD (15.6\%). PM-URD showed the highest 5-year NRM rate at 29.3\% (Figure 2D). Overall, MSD, WM-URD, and FMMT showed similar 5-year OS (63.1\%) and DFS $(62.0 \%)$ rates, which were significantly superior to AUTO ( $p=0.006$ and $p<0.001$, respectively) and PMURD ( $p<0.001$ and $p<0.001$, respectively). PM-URD had a higher NRM rate compared to AUTO $(p<0.001)$, 
Table 3: Multivariate analysis of affecting factors for DFS and CIR.

\begin{tabular}{|c|c|c|c|c|c|c|c|c|}
\hline \multirow{3}{*}{ Variables } & \multicolumn{4}{|c|}{ Disease free survival (DFS) } & \multicolumn{4}{|c|}{ Cumulative incidence of relapse (CIR) } \\
\hline & \multicolumn{2}{|c|}{$\begin{array}{l}\text { Univariate } \\
\end{array}$} & \multicolumn{2}{|c|}{ Multivariate } & \multicolumn{2}{|c|}{$\begin{array}{l}\text { Univariate } \\
\end{array}$} & \multicolumn{2}{|c|}{ Multivariate } \\
\hline & $\begin{array}{l}\text { 5-year } \\
\text { DFS }\end{array}$ & $p$ & $\begin{array}{l}\text { HR } \\
(95 \% \mathrm{CI})\end{array}$ & $p$ & $\begin{array}{l}\text { 5-year } \\
\text { CIR }\end{array}$ & $p$ & $\begin{array}{l}\mathrm{HR} \\
(95 \% \mathrm{CI})\end{array}$ & $p$ \\
\hline \multicolumn{9}{|l|}{ Age at diagnosis } \\
\hline$\leq 40$ years old $(n=283)$ & $57.9 \%$ & 0.458 & & & $32.8 \%$ & 0.217 & & \\
\hline$>40$ years old $(n=278)$ & $55.4 \%$ & & & & $28.6 \%$ & & & \\
\hline \multicolumn{9}{|l|}{ Gender } \\
\hline $\begin{array}{l}\text { Male }(n=295) \\
\text { Female }(n=266)\end{array}$ & $\begin{array}{l}53.9 \% \\
59.8 \%\end{array}$ & 0.345 & & & $\begin{array}{l}31.5 \% \\
29.7 \%\end{array}$ & 0.913 & & \\
\hline \multicolumn{9}{|l|}{ Karyotype } \\
\hline Intermediate-risk $(\mathrm{n}=417)$ & $62.7 \%$ & $<0.001 *$ & 1 & - & $24.8 \%$ & $<0.001 *$ & 1 & - \\
\hline Poor-risk (n=144) & $38.7 \%$ & & $\begin{array}{l}1.807 \\
(1.4-2.4)\end{array}$ & $<0.001 *$ & $48.1 \%$ & & $\begin{array}{l}2.105 \\
(1.5-2.9)\end{array}$ & $<0.001 *$ \\
\hline $\begin{array}{l}\text { Pre-HCT chemotherapy } \\
\text { Idarubicin+BHAC }(n=338) \\
\text { Idarubicin+cytarabine }(n=223)\end{array}$ & $\begin{array}{l}59.4 \% \\
51.0 \%\end{array}$ & 0.282 & & & $\begin{array}{l}28.2 \% \\
34.8 \%\end{array}$ & 0.169 & & \\
\hline \multicolumn{9}{|l|}{ Number of inductions to $\mathrm{CR}$} \\
\hline 1 cycle $(n=491)$ & $59.3 \%$ & $0.003 *$ & 1 & - & $28.9 \%$ & 0.071 & 1 & - \\
\hline 2 or more cycles $(n=70)$ & $39.4 \%$ & & $\begin{array}{l}1.567 \\
(1.1-2.3)\end{array}$ & $0.017^{*}$ & $42.8 \%$ & & $\begin{array}{l}1.649 \\
(1.1-2.6)\end{array}$ & $0.027 *$ \\
\hline $\begin{array}{l}\text { Time from induction to HCT } \\
\quad<7 \text { months }(\mathrm{n}=417) \\
\geq 7 \text { months }(\mathrm{n}=144)\end{array}$ & $\begin{array}{l}60.0 \% \\
46.8 \%\end{array}$ & $<0.001^{*}$ & & & $\begin{array}{l}27.7 \% \\
39.1 \%\end{array}$ & $0.002 *$ & & \\
\hline \multicolumn{9}{|l|}{ Conditioning regiment intensity } \\
\hline $\begin{array}{l}\text { MAC }(n=463) \\
\text { RIC }(n=98)\end{array}$ & $\begin{array}{l}55.1 \% \\
64.9 \%\end{array}$ & 0.081 & & & $\begin{array}{l}32.8 \% \\
20.3 \%\end{array}$ & $0.006^{*}$ & & \\
\hline \multicolumn{9}{|l|}{ Donor source } \\
\hline $\operatorname{MSD}(\mathrm{n}=252)$ & $61.4 \%$ & $0.001 *$ & 1 & - & $23.5 \%$ & $<0.001 *$ & 1 & - \\
\hline WM-URD (n=112) & $62.1 \%$ & & $\begin{array}{l}0.874 \\
(0.6-1.3)\end{array}$ & 0.480 & $30.3 \%$ & & $\begin{array}{l}1.126 \\
(0.7-1.7)\end{array}$ & 0.598 \\
\hline FMMT $(\mathrm{n}=52)$ & $65.3 \%$ & & $\begin{array}{l}0.909 \\
(0.4-1.9)\end{array}$ & 0.795 & $18.5 \%$ & & $\begin{array}{l}1.182 \\
(0.4-3.2)\end{array}$ & 0.746 \\
\hline Autologous HCT (n=104) & $44.7 \%$ & & $\begin{array}{l}1.370 \\
(0.9-2.0)\end{array}$ & 0.091 & $51.0 \%$ & & $\begin{array}{l}1.962 \\
(1.3-3.0)\end{array}$ & $0.002 *$ \\
\hline PM-URD $(\mathrm{n}=41)$ & $36.8 \%$ & & $\begin{array}{l}1.638 \\
(1.0-2.6)\end{array}$ & $0.033^{*}$ & $33.9 \%$ & & $\begin{array}{l}1.412 \\
(0.8-2.6)\end{array}$ & 0.273 \\
\hline \multicolumn{9}{|l|}{ Acute GVHD > Grade II } \\
\hline $\begin{array}{l}\text { No }(n=381) \\
\text { Yes }(n=180)\end{array}$ & $\begin{array}{l}59.0 \% \\
52.1 \%\end{array}$ & 0.152 & & & $\begin{array}{l}33.3 \% \\
24.6 \%\end{array}$ & $0.043^{*}$ & & \\
\hline \multicolumn{9}{|l|}{ Chronic GVHD ( $\geq$ Moderate) } \\
\hline Yes $(n=140)$ & $66.4 \%$ & $<0.001 *$ & 1 & - & $15.4 \%$ & $<0.001 *$ & 1 & - \\
\hline No $(n=421)$ & $53.6 \%$ & & $\begin{array}{l}1.649 \\
(1.2-2.3)\end{array}$ & $0.005^{*}$ & $35.6 \%$ & & $\begin{array}{l}2.704 \\
(1.6-4.5)\end{array}$ & $<0.001^{*}$ \\
\hline
\end{tabular}

${ }^{*} p<0.005$

Abbreviation: HR, hazard ratio; HCT, hematopoietic cell transplantation; BHAC, N4-behenoyl-1- $\beta$-D-arabinofuranosyl cytosine; CR, complete remission; MAC, myeloablative conditioning; RIC, Reduced intensity conditioning; TBI, total body irradiation; MSD, matched sibling donor; WM-URD, well-matched unrelated donor; FMMT, familial mismatched transplantation; PM-URD, partially-matched unrelated donor; GVHD, graft-vs.-host disease; Mod, moderate;

WM-URD $(p<0.001)$, FMMT $(p=0.079)$, and MSD $(p=$ 0.043). Except for AUTO-HCT, the other donor types did not show significantly-different CIR rates (e.g., FMMT vs. PM-URD, $p=0.219$ ).

\section{GVHD and cytomegalovirus (CMV) reactivation}

We analyzed the incidence of GVHD and CMV reactivation according to the donor types, except for AUTO-HCT. The incidence of acute GVHD $\geq$ grade II was higher in URD-HCT (48.8\% in PM-URD and $47.3 \%$ in WM-URD) compared to FMMT $(36.5 \%, p=0.023)$ and MSD-HCT $(34.6 \%, p=0.021)$. However, the incidence of acute GVHD $\geq$ grade III was higher in PM-URD (29.3\%) and FMMT (15.4\%) compared to MSD-HCT (8.7\%) and WM-URD (6.3\%). As shown in Figure 3A, PM-URD had a significantly higher proportion of acute GVHD $\geq$ grade III compared to WM-URD and MSD $(p<0.001)$. The incidence of chronic GVHD was similar in all donor types $(55.2 \%$ in MSD, $45.8 \%$ in WM-URD, $41.5 \%$ in PM- 
URD, and 56.3\% in FMMT). Moderate to severe chronic GVHD also occurred at a similar rate in MSD (34.4\%), WM-URD (27.8\%), PM-URD (22.0\%), and FMMT $(27.3 \%)$ without a significant difference (Figure $3 \mathrm{~B}, p=$ $0.227)$. We analyzed the incidence of CMV reactivation (defined as more than 1,000 copies/mL) and identified that PM-URD and FMMT showed a higher incidence of CMV reactivation compared to MSD and WM-URD $(88.3 \%$ and $82.7 \%$ vs. $62.0 \%$ and $66.0 \%$, respectively, $p<0.001$ ) (Figure $3 \mathrm{C}$ ). When $\mathrm{CMV}$ reactivation was defined as more than 10,000 copies/mL (Figure 3D), PM-URD and FMMT also showed a higher incidence of CMV reactivation compared to MSD and WM-URD (51.4\% and 54.4\% vs. $25.3 \%$ and $33.5 \%$, respectively, $p<0.001)$.

\section{Subgroup analysis}

In the intermediate-risk subgroup, the 5-year DFS for PM-URD and AUTO-HCT was $48.0 \%$ and $53.9 \%$, respectively, which was inferior to $\operatorname{MSD}(65.9 \%, p=$ 0.055 for PM-URD and $p=0.031$ for AUTO-HCT), FMMT $(68.5 \%, p=0.097$ for PM-URD and $p=0.176$ for AUTO-HCT), and WM-URD $(80.9 \%, p=0.080$ for PM-URD and $p=0.081$ for AUTO-HCT) (Figure 4A). For CIR (Figure 4B) and NRM rates, only AUTO-HCT showed a significantly-higher 5-year CIR rate (40.6\%) compared to other donor types (range, 13.4\%-25.6\%, $p$ $=0.058$ to 0.007 ), and only PM-URD showed a higher 5 -year NRM rate $(34.5 \%)$ compared to other donor types (range, 5.1\%-18.0\%, $p=0.093$ to $<0.001$ ). PM-URD showed high incidences of both acute GVHD $\geq$ grade III (31.0\%) and CMV reactivation of over 10,000 copies/mL $(45.1 \%)$ in the intermediate-risk subgroup. In the poor-risk subgroup, the 5-year DFS for PM-URD and AUTO-HCT was $12.6 \%$ and $0.0 \%$, respectively, which was inferior to MSD (46.7\%, $p=0.028$ for PM-URD and $p=0.007$ for AUTO-HCT), FMMT $(59.8 \%, p=0.031$ for PM-URD and $p=0.015$ for AUTO-HCT), and WM-URD (48.4\%, $p=0.018$ for PM-URD and $p=0.006$ for AUTO-HCT) (Figure 4C). We also identified that AUTO-HCT had a higher 5-year CIR rate (87.1\%) compared to MSD (32.1\%, $p<0.001)$, WM-URD (41.8\%, $p<0.001)$, and FMMT $(32.5 \%, p=0.005)$, but the rate was not significantly higher than PM-URD $(83.3 \%, p=0.235)$ (Figure 4D). The CIR rate for PM-URD was significantly higher only compared to $\operatorname{MSD}(p=0.016)$.

\section{Multivariate analysis}

Table 3 shows an analysis of the independent factors affecting DFS and CIR rates after HCT in the first remission. Univariate analysis showed that age, gender, and differences in pre-HCT chemotherapy did not affect DFS or CIR in this cohort. For both DFS and CIR, the proven adverse factors were the poor-risk karyotype, more than 2 induction chemotherapies to achieve first remission, time to $\mathrm{HCT}$, conditioning intensity, donor types (PM-URD or AUTO-HCT), acute GVHD (only for CIR), and the absence of chronic GVHD, which were all adjusted for in multivariate analysis to a significance of $p<0.100$. The multivariate analysis revealed that poor DFS was associated with the poor-risk karyotype (HR = 1.807 (95\% CI, 1.4-2.4), $p<0.001)$, more than 2 induction chemotherapies to achieve first remission $(\mathrm{HR}=1.567$ (95\% CI, 1.1-2.3), $p=0.017)$, PM-URD (HR $=1.638$ $(95 \% \mathrm{CI}, 1.0-2.6), p=0.033)$, and the absence of chronic GVHD $(\mathrm{HR}=1.649(95 \% \mathrm{CI}, 1.2-2.3), p=0.005)$. Higher CIR rates were associated with the poor-risk karyotype $(\mathrm{HR}=2.105(95 \% \mathrm{CI}, 1.5-2.9), p<0.001)$, more than 2 induction chemotherapies to achieve first remission (HR $=1.649(95 \% \mathrm{CI}, 1.1-2.6), p=0.027)$, AUTO-HCT $(\mathrm{HR}$ $=1.962(95 \% \mathrm{CI}, 1.3-3.0), p=0.002)$, and the absence of chronic GVHD (HR = 2.704 (95\% CI, 1.6-4.5), $p<$ $0.001)$. The risk factors for a higher rate of NRM were an age of more than 40 years old (HR $=1.729(95 \% \mathrm{CI}, 1.1$ $2.8), p=0.023)$, acute GVHD $\geq$ Grade III $(\mathrm{HR}=2.483$ (95\% CI, 1.5-4.0), $p<0.001)$, and PM-URD (HR = 3.781 (95\% CI, 1.3-11.2), $p=0.016$, compared to AUTO-HCT).

\section{DISCUSSION}

In the current study, we observed favorable treatment outcomes with FMMT compared to standard donor types. FMMT showed the lowest CIR rate with favorable OS and DFS rates that were comparable to MSD-HCT. The clinical outcomes of MSD, WM-URD, and FMMT were all similar in terms of OS, DFS, CIR, and NRM rates. These data suggest that frontline FMMT can be a feasible choice when MSD is unavailable prior to an URD search. In several previous studies, FMMT was compared retrospectively to chemotherapy alone, as well as WM-URD and PM-URD transplantation [19, 32-34], all of which indicated that frontline FMMT might be a good alternative choice for intermediate- to poor-risk AML. However, the limitations of a retrospective design, short follow-up duration, and different treatment modalities using post-HCT cyclophosphamide made this conclusion uncertain. Recently, a prospective multicenter clinical trial comparing the outcomes of FMMT and MSD in treating intermediate- to poor-risk adult AML in CR1 was performed. Wang et al. reported that the clinical outcomes were similar between the 2 groups and that the 3-year OS, DFS, CIR, and NRM rates for FMMT were 79\%, 74\%, $15 \%$, and $13 \%$, respectively [25]. They suggested that FMMT was a valid alternative for intermediate- to poorrisk AML patients in CR1 when MSD is not available. However, the study also had the limitations that the patients could not be randomized for ethical and practical reasons and that there were several imbalanced features, such as age and the proportion of poor-risk patients, between the two groups. Our data showed that the 5-year 
OS, DFS, CIR, and NRM rates for FMMT were $65.1 \%$, $65.3 \%, 18.5 \%$, and $15.7 \%$, respectively, which were similar to the results from MSD and WM-URD. The intermediate-risk and poor-risk subgroup analysis, as well as the multivariate analysis, confirmed the positive clinical outcomes for FMMT. Based on these results, we are now conducting a prospective clinical trial evaluating the outcomes of FMMT versus WM-URD transplantation (\#NCT01751997).

For FMMT, we applied a novel conditioning regimen consisting of intermediate-dose TBI (800 cGy), fludarabine, busulfan, and low-dose ATG, along with a CD34+ stem-cell dose of at least $5.0 \times 10^{6}$ cells $/ \mathrm{kg}$, which, as reported previously, showed a prompt and sustained engraftment with no graft failure [19, 35, 36]. This regimen was used in 80 patients comprising all risk karyotypes and showed a low NRM (12.2\%) rate and good OS when patients were in CR1 before HCT [35]. Although FMMT had a high incidence of acute GVHD $\geq$ grade III and CMV reactivation (which is significantly higher than in Western reports due to a high prevalence of CMV infection in Korea) similar to PM-URD, most of the incidences were safely managed. The main limitation of the analysis was the shorter median follow-up duration compared to the other donor types since FMMT was actively performed only after 2008 .

In our transplantation center, PM-URD was the primary alternative donor type until 2012, but FMMT is now preferred over PM-URD. The poorer outcomes of PM-URD have been reported in several studies [22, 37], but few studies compared the outcomes of PM-URD and standard donors in adult AML. Our data support the previous results from the Center for International Blood and Marrow Transplant Research data, which showed poorer survival outcomes and significantly higher NRM rates with PM-URD [18]. One difference in our data was that the 12 patients with the poor-risk karyotype who received PM-URD transplants showed a high relapse rate $(n=8,61.1 \%)$, which was not significantly different compared to that of AUTO-HCT. This result might be biased by the small number of patients in the PM-URD group who had an extremely poor karyotype including complex karyotype $(n=5)$, monosomal karyotype $(n=$ $2)$, chromosome 3 or 5 abnormalities $(n=4)$, and $\mathrm{t}(6 ; 11)$ $(n=1)$. In addition, 9 of those patients were transplanted before 2008. Nevertheless, our data suggests that FMMT can be considered prior to PM-URD, especially in cases with an urgent need for HCT. Additionally, if PM-URD is required, the dose of ATG, methotrexate, or calcineurin inhibitor should be modified to prevent severe GVHD, and CMV reactivation should be closely monitored.

Notably, our data revealed that AUTO-HCT showed acceptable OS and DFS rates, characterized by the lowest NRM rate and the highest CIR rate compared to standard allogeneic-HCT, especially in the intermediate-risk subgroup. Previous clinical trials that showed a longer duration of recovery evaluated AUTO-HCT using BMderived progenitor cells, but recent studies have shown that PB autografts have a lower NRM rate with early hematopoietic recovery. Therefore, if we are considering AUTO-HCT, our present goal is a reduction of the relapse rate, which requires a good candidate for AUTO-HCT and a leukemia-free graft. Recent data revealed that AUTO-HCT showed a lower relapse rate compared to consolidation chemotherapy alone [38, 39], and a lower NRM rate compared to allogeneic-HCT [16]. However, our data suggests that we should avoid AUTO-HCT and consider allogeneic-HCT from standard donors or FMMT for poor-risk AML patients. Improved supportive care and techniques for stem cell mobilization may expand the application of AUTO-HCT, and post-HCT maintenance therapy can be used for the prevention of relapse [40]. We identified 52 (50\%) relapsed patients among the 104 patients treated with AUTO-HCT. Among the 52 relapsed patients, 12 were treated with allogeneic-HCT and $6(50 \%)$ of those patients are alive without relapse. However, failure to prior treatment was basically refractory to the salvage chemotherapy, and our data included only a small number of patients with possible selection bias although the result was superior to the OS rates (4-20\%) of previous reports $[41,42]$.

We have another alternative donor source, which was not used in this study. Cord blood transplantation (CBT) has been used in patients with acute lymphoblastic leukemia and AML, and many reports showed encouraging treatment outcomes compared to URDHCT, especially to PM-URD [43, 44]. In addition, since a recent study suggested that $\mathrm{CBT}$ showed similar clinical outcomes compared to FMMT [45], we may use both CBT and FMMT as an alternative donor type for patients lacking HLA-matched donors when allogeneic-HCT cannot be delayed. In our center, CBT is used for patients who relapse after FMMT, but comparative clinical trials, including qualified cord blood cell dose and optimization of pre-conditioning regimen, should be designed in near future.

Although this study is a retrospective analysis of a heterogeneous cohort over a wide transplant time period, all of which may induce bias, our observations are based on a consistent treatment strategy, including pre-HCT chemotherapy, donor searching sequence, conditioning regimens, immunosuppressive agents, and supportive care, without significant change over time. In addition, since molecular markers were not analyzed for all patients due to unavailable data, some favorable-risk CN-AML patients might be distributed in the intermediate-risk group in this study. However, the proportion would be very small and we reasonably showed the clinical outcomes of all possible donor types simultaneously. In conclusion, our data suggests that FMMT can be a good alternative for intermediate- to poor-risk adult AML patients, and we also identified the possible use of AUTO-HCT for selected 
patients in the intermediate-risk subgroup. These results should be validated in large prospective studies in the future.

\section{MATERIALS AND METHODS}

\section{Enrolled patients}

We initially found 904 adult AML patients (median age: 40 years old, range: 16-69) who underwent HCT treatment at the Catholic Blood and Marrow Transplantation Center of South Korea between 2002 and 2013. All patients were diagnosed morphologically by bone marrow (BM) aspiration and biopsy samples followed by immunophenotypic and cytogenetic analysis. For karyotyping, at least 20 metaphases from BM cells were analyzed using the GTG banding method after 24 or $48 \mathrm{~h}$ of unsynchronized culture, and the International System for Cytogenetic Nomenclature (ISCN) [46] and National Comprehensive Cancer Network [47] were used as guidelines for classification. As HCT is not regarded as a standard therapy for favorable-risk AML patients, we excluded 203 patients with favorable-risk molecular cytogenetics. In addition, we excluded patients who were treated with induction chemotherapy with reduced intensity due to age and severe comorbidity ( $n$ $=24$ ). To include only patients in their first remission before HCT, we also excluded non-remission patients $(n=24)$, patients in their second remission $(n=27)$ before HCT, and patients treated with second HCT $(n=50)$. The final group contained 561 patients with intermediate- or poor-risk molecular cytogenetics who underwent HCT in their first remission after intensive chemotherapy. Among them, there were 417 patients in the intermediate-risk group and 144 patients in the poorrisk group (Figure 1). This research was conducted in accordance with the Institutional Review Board and Ethics Committee guidelines of the Catholic Medical Center (KC16RISI0002) and the principles of the Declaration of Helsinki.

\section{Molecular studies}

All molecular studies were performed using initial BM samples at diagnosis. We screened 28 genetic aberrations using multiplex reverse-transcriptase polymerase chain reaction (RT-PCR) using the HemaVision Kit (DNA Technology, Aarthus, Denmark). Mutations and expression of NPM1 were determined by real-time quantitative (RQ)-PCR using the NPMI MutaQuant ${ }^{\mathrm{TM}}$ kit (Ipsogen, Marseille, France), and the FLT3-ITD mutation was evaluated with multiplex allelespecific PCR (ABSOLUTETM FLT3 TKD/ITD PCR; Biosewoom, Seoul, Korea). C-kit mutations were detected using melting curve analysis using RT-PCR (Real-Q C-KIT screening kit and D816muta-ID kit, Biosewoom, Korea), which can detect the $c$-kit mutations located at Asp816 (D816) and Asn822 (N822K) in exon 17. These molecular studies began after 2008, and many patients from before that time did not have BM samples available for the molecular studies. Those patients were stratified only with karyotype results.

\section{Chemotherapy and transplantation procedure}

All patients were treated according to our standard protocol, consisting of ' $3+7$ ' idarubicin (IDA, $\left.12 \mathrm{mg} / \mathrm{m}^{2}\right)$ plus ARA-C $\left(100 \mathrm{mg} / \mathrm{m}^{2}\right.$ continuously infused for 24 hours) or Behenoyl cytarabine (BHAC, $300 \mathrm{mg} / \mathrm{m}^{2}$ ), an analog of cytarabine, for remissioninduction chemotherapy. After achieving CR, one or two consolidation chemotherapies were administered. Our standard consolidation chemotherapy consisted of ' $3+5$ ' mitoxantrone ( $12 \mathrm{mg} / \mathrm{m}^{2}$ iv) or IDA $\left(12 \mathrm{mg} / \mathrm{m}^{2}\right)$ plus an intermediate dose of ARA-C $\left(1.0 \mathrm{~g} / \mathrm{m}^{2}\right.$ iv bid $)$, which were alternated. In patients who were treated with BHAC for induction chemotherapy, BHAC was used for consolidation instead of ARA-C. After 2010, patients were treated with only ARA-C-based chemotherapy. During consolidation, we searched for available donors for allogeneic-HCT with a preference of MSD first, followed by WM-URD, then PM-URD. Before 2005, HLA typing was done by serology, and high-resolution sequencebased typing was used after that time. Therefore, before 2005, URD-HCT was with PM-URD. In the absence of conventional donors, FMMT or AUTO were used according to the patient's and physician's choice. If a patient was a candidate for AUTO, CD34+ stem cells were collected for 3 days when the neutrophil count recovered during the course of 2 consolidation chemotherapies. For donor mobilization, we administered G-CSF subcutaneously at a dose of $10 \mathrm{mcg} / \mathrm{kg} / \mathrm{day}$ for 4 days.

Patients who underwent HCT from MSD, WMURD, and PM-URD received either a MAC regimen or a RIC regimen. For the MAC regimen, briefly, we administered cyclophosphamide $(120 \mathrm{mg} / \mathrm{kg})$ combined with TBI (1320 cGy) or busulfan $(12.8 \mathrm{mg} / \mathrm{kg})$. A small proportion of patients received TBI (1320 cGy) plus busulfan $(12.8 \mathrm{mg} / \mathrm{kg})$ or TBI (1200 cGy) plus ARA-C $(9 \mathrm{~g} / \mathrm{BSA})$ and melphalan $(100 \mathrm{mg} / \mathrm{BSA})$, which is mainly used in AUTO [48]. For the RIC regimen, we administered busulfan $(6.4 \mathrm{mg} / \mathrm{kg})$ and fludarabine $\left(150 \mathrm{mg} / \mathrm{m}^{2}\right)$ with 400 cGy of TBI. Anti-thymocyte globulin (ATG) at a dose of $2.5 \mathrm{mg} / \mathrm{kg}(1.25 \mathrm{mg} / \mathrm{kg}$ on D-3 and D-2) was administered for patients receiving stem cells from PMURD. For FMMT, we administered fludarabine $(150 \mathrm{mg} /$ $\left.\mathrm{m}^{2}\right)$ and busulfan $(6.4 \mathrm{mg} / \mathrm{kg})$ with $800 \mathrm{cGy}$ of TBI and ATG at a dose of $5 \mathrm{mg} / \mathrm{kg}(1.25 \mathrm{mg} / \mathrm{kg}$ on D-4 to D-1), all of which were described previously [19,35]. We initially recommended BM for the stem cell source, and many of 
the MSD agreed, but many URD preferred PB. For FMMT and AUTO, we primarily used PB as the stem cell source, but some AUTO cases concomitantly used BM due to the lack of CD34+ stem cells.

\section{GVHD prophylaxis and supportive care}

GVHD prophylaxis was administered using a calcineurin inhibitor plus a short course of methotrexate $\left(5 \mathrm{mg} / \mathrm{m}^{2}\right.$ for tacrolimus and $10 \mathrm{mg} / \mathrm{m}^{2}$ for cyclosporine) on D1, D3, D6, and D11. We used cyclosporine for MSDHCT and tacrolimus for both URD-HCT and FMT. Evaluation and management of acute and chronic GVHD were based on the recommendations of the National Institutes of Health [49-51]. We used acyclovir and itraconazole for prophylaxis, and ciprofloxacin was used for prophylactic gut decontamination. After engraftment, we administered cotrimoxazole for $P$. jirovecii pneumonia prophylaxis. For surveillance of CMV reactivation, we checked RQ-PCR for CMV DNA after neutrophil engraftment and monitored for $\mathrm{CMV}$ reactivation twice a week until discharge. During the follow-up at the outpatient clinic, patients were monitored weekly or biweekly until the cessation of the immunosuppressive drugs. According to the CMV RQ-PCR level, risk-adapted preemptive ganciclovir therapy was conducted to prevent CMV disease. Patients were classified into low- and poorrisk groups according to both $\mathrm{HCT}$ type and the grade of GVHD based on our previous protocol $[52,53]$.

\section{Statistical analysis}

In this study, we divided patients into 5 groups according to the HCT donor types and compared the treatment outcomes. Between the groups, we compared OS, DFS, CIR, and NRM rates in association with the incidence of GVHD and CMV reactivation. All categorical variables were compared using Chi-squared analysis and continuous variables were assessed with the Student's $t$-test and one-way analysis of variance. OS and DFS was calculated using Kaplan-Meier analysis, and logrank analysis was used to evaluate differences between the groups. OS represented the proportion of people who were alive at a specified time from the date of allogeneicHCT and DFS took into account death, relapse, lost to follow-up as the result of treatment complications. CIR and NRM were calculated by cumulative incidence estimation treating non-relapse deaths and relapse as competing risks, respectively, and compared using the Gray test [54]. Survival hazard ratio was calculated using Cox's proportional model. All statistical analyses were performed using SAS 9.2 software (SAS Institute, Inc., Cary, NC) and R software (version 2.15.1, R foundation for statistical Computing, 2012). Statistical significance was determined with $p$-value $<0.05$.

\section{ACKNOWLEDGMENTS}

This study was supported by Research Fund of Seoul St. Mary's Hospital, The Catholic University of Korea, and also supported by a grant from the Basic Science Research Program through the National Research Foundation of Korea (NRF) funded by the Ministry of Education (2015R1D1A1A01059819).

\section{CONFLICTS OF INTEREST}

We declare that none of the authors have any financial interests related to this work.

\section{REFERENCES}

1. Gorin NC, Labopin M, Frassoni F, Milpied N, Attal M, Blaise D, Meloni G, Iori AP, Michallet M, Willemze R, Deconninck E, Harousseau JL, Polge E, Rocha V. Identical outcome after autologous or allogeneic genoidentical hematopoietic stem-cell transplantation in first remission of acute myelocytic leukemia carrying inversion 16 or $\mathrm{t}(8 ; 21)$ : a retrospective study from the European Cooperative Group for Blood and Marrow Transplantation. J Clin Oncol. 2008; $26: 3183-88$

2. Fernandez HF, Sun Z, Litzow MR, Luger SM, Paietta EM, Racevskis J, Dewald G, Ketterling RP, Rowe JM, Lazarus HM, Tallman MS. Autologous transplantation gives encouraging results for young adults with favorablerisk acute myeloid leukemia, but is not improved with gemtuzumab ozogamicin. Blood. 2011; 117:5306-13.

3. Guièze $\mathrm{R}$, Cornillet-Lefebvre $\mathrm{P}$, Lioure $\mathrm{B}$, Blanchet $\mathrm{O}$, Pigneux A, Recher C, Bonmati C, Fegueux N, Bulabois CE, Bouscary D, Vey N, Delain M, Turlure P, et al. Role of autologous hematopoietic stem cell transplantation according to the NPM1/FLT3-ITD molecular status for cytogenetically normal AML patients: a GOELAMS study. Am J Hematol. 2012; 87:1052-56.

4. Schlenk RF, Taskesen E, van Norden Y, Krauter J, Ganser A, Bullinger L, Gaidzik VI, Paschka P, Corbacioglu A, Göhring G, Kündgen A, Held G, Götze K, et al. The value of allogeneic and autologous hematopoietic stem cell transplantation in prognostically favorable acute myeloid leukemia with double mutant CEBPA. Blood. 2013; 122:1576-82.

5. Eom KS, Kim HJ, Cho BS, Lee SE, Yahng SA, Yoon JH, Shin SH, Jeon YW, Kim JH, Kim YJ, Lee S, Min CK, Cho SG, et al. Equivalent outcome of autologous stem cell transplantation and reduced intensity conditioning stem cell transplantation in acute myeloid leukemia patients with t(8;21). Acta Haematol. 2015; 133:266-76.

6. Yoshimoto G, Nagafuji K, Miyamoto T, Kinukawa N, Takase K, Eto T, Kato K, Hayashi S, Kamimura T, Ohno Y, Taniguchi S, Harada M. FLT3 mutations in normal karyotype acute myeloid leukemia in first complete 
remission treated with autologous peripheral blood stem cell transplantation. Bone Marrow Transplant. 2005; 36:977-83.

7. Jung AS, Holman PR, Castro JE, Carrier EK, Bashey A, Lane TA, Nelson CL, Pu M, Messer K, Corringham SM, Ball ED. Autologous hematopoietic stem cell transplantation as an intensive consolidation therapy for adult patients in remission from acute myelogenous leukemia. Biol Blood Marrow Transplant. 2009; 15:130613.

8. Nagler A, Labopin M, Gorin NC, Ferrara F, Sanz MA, Wu D, Gomez AT, Lapusan S, Irrera G, Guimaraes JE, Sousa AB, Carella AM, Vey N, et al. Intravenous busulfan for autologous stem cell transplantation in adult patients with acute myeloid leukemia: a survey of 952 patients on behalf of the Acute Leukemia Working Party of the European Group for Blood and Marrow Transplantation. Haematologica. 2014; 99:1380-86.

9. Cornelissen JJ, Blaise D. Hematopoietic stem cell transplantation for patients with AML in first complete remission. Blood. 2016; 127:62-70.

10. Claude Gorin N. Autologous stem cell transplantation versus alternative allogeneic donor transplants in adult acute leukemias. Semin Hematol. 2016; 53:103-10.

11. Yanada M, Matsuo K, Emi N, Naoe T. Efficacy of allogeneic hematopoietic stem cell transplantation depends on cytogenetic risk for acute myeloid leukemia in first disease remission: a metaanalysis. Cancer. 2005; 103:165258.

12. Cornelissen JJ, van Putten WL, Verdonck LF, Theobald M, Jacky E, Daenen SM, van Marwijk Kooy M, Wijermans P, Schouten H, Huijgens PC, van der Lelie H, Fey M, Ferrant A, et al. Results of a HOVON/SAKK donor versus no-donor analysis of myeloablative HLA-identical sibling stem cell transplantation in first remission acute myeloid leukemia in young and middle-aged adults: benefits for whom? Blood. 2007; 109:3658-66.

13. Koreth J, Schlenk R, Kopecky KJ, Honda S, Sierra J, Djulbegovic BJ, Wadleigh M, DeAngelo DJ, Stone RM, Sakamaki H, Appelbaum FR, Döhner H, Antin JH, et al. Allogeneic stem cell transplantation for acute myeloid leukemia in first complete remission: systematic review and meta-analysis of prospective clinical trials. JAMA. 2009; 301:2349-61.

14. Aversa F. Haploidentical haematopoietic stem cell transplantation for acute leukaemia in adults: experience in Europe and the United States. Bone Marrow Transplant. 2008; 41:473-81.

15. Ruggeri A, Ciceri F, Gluckman E, Labopin M, Rocha V, and Eurocord and Acute Leukemia Working Party of the European Blood and Marrow Transplant Group. Alternative donors hematopoietic stem cells transplantation for adults with acute myeloid leukemia: umbilical cord blood or haploidentical donors? Best Pract Res Clin Haematol. 2010; 23:207-16.

16. Keating A, DaSilva G, Pérez WS, Gupta V, Cutler
CS, Ballen KK, Cairo MS, Camitta BM, Champlin RE, Gajewski JL, Lazarus HM, Lill M, Marks DI, et al. Autologous blood cell transplantation versus HLA-identical sibling transplantation for acute myeloid leukemia in first complete remission: a registry study from the Center for International Blood and Marrow Transplantation Research. Haematologica. 2013; 98:185-92.

17. Yakoub-Agha I, Mesnil F, Kuentz M, Boiron JM, Ifrah N, Milpied N, Chehata S, Esperou H, Vernant JP, Michallet M, Buzyn A, Gratecos N, Cahn JY, et al. Allogeneic marrow stem-cell transplantation from human leukocyte antigenidentical siblings versus human leukocyte antigen-allelicmatched unrelated donors (10/10) in patients with standardrisk hematologic malignancy: a prospective study from the French Society of Bone Marrow Transplantation and Cell Therapy. J Clin Oncol. 2006; 24:5695-702.

18. Gupta V, Tallman MS, He W, Logan BR, Copelan E, Gale RP, Khoury HJ, Klumpp T, Koreth J, Lazarus HM, Marks DI, Martino R, Rizzieri DA, et al. Comparable survival after HLA-well-matched unrelated or matched sibling donor transplantation for acute myeloid leukemia in first remission with unfavorable cytogenetics at diagnosis. Blood. 2010; 116:1839-48.

19. Cho BS, Yoon JH, Shin SH, Yahng SA, Lee SE, Eom KS, Kim YJ, Lee S, Min CK, Cho SG, Kim DW, Lee JW, Min WS, et al. Comparison of allogeneic stem cell transplantation from familial-mismatched/haploidentical donors and from unrelated donors in adults with highrisk acute myelogenous leukemia. Biol Blood Marrow Transplant. 2012; 18:1552-63.

20. Beatty PG, Clift RA, Mickelson EM, Nisperos BB, Flournoy N, Martin PJ, Sanders JE, Stewart P, Buckner CD, Storb R, Thomas ED, Hansen JA. Marrow transplantation from related donors other than HLA-identical siblings. N Engl J Med. 1985; 313:765-71.

21. Anasetti C, Hansen JA. Effect of HLA incompatibility in marrow transplantation from unrelated and HLAmismatched related donors. Transfus Sci. 1994; 15:221-30.

22. Lee SJ, Klein J, Haagenson M, Baxter-Lowe LA, Confer DL, Eapen M, Fernandez-Vina M, Flomenberg N, Horowitz M, Hurley CK, Noreen H, Oudshoorn M, Petersdorf E, et al. High-resolution donor-recipient HLA matching contributes to the success of unrelated donor marrow transplantation. Blood. 2007; 110:4576-83.

23. Aversa F, Terenzi A, Tabilio A, Falzetti F, Carotti A, Ballanti S, Felicini R, Falcinelli F, Velardi A, Ruggeri L, Aloisi T, Saab JP, Santucci A, et al. Full haplotypemismatched hematopoietic stem-cell transplantation: a phase II study in patients with acute leukemia at high risk of relapse. J Clin Oncol. 2005; 23:3447-54.

24. Ciceri F, Labopin M, Aversa F, Rowe JM, Bunjes D, Lewalle P, Nagler A, Di Bartolomeo P, Lacerda JF, Lupo Stanghellini MT, Polge E, Frassoni F, Martelli MF, et al. A survey of fully haploidentical hematopoietic stem cell transplantation in adults with high-risk acute leukemia: a 
risk factor analysis of outcomes for patients in remission at transplantation. Blood. 2008; 112:3574-81.

25. Wang Y, Liu QF, Xu LP, Liu KY, Zhang XH, Ma X, Fan ZP, Wu DP, Huang XJ. Haploidentical vs identical-sibling transplant for AML in remission: a multicenter, prospective study. Blood. 2015; 125:3956-62.

26. Luznik L, Bolaños-Meade J, Zahurak M, Chen AR, Smith BD, Brodsky R, Huff CA, Borrello I, Matsui W, Powell JD, Kasamon Y, Goodman SN, Hess A, et al. High-dose cyclophosphamide as single-agent, short-course prophylaxis of graft-versus-host disease. Blood. 2010; 115:3224-30.

27. Robinson TM, O’Donnell PV, Fuchs EJ, Luznik L. Haploidentical bone marrow and stem cell transplantation: experience with post-transplantation cyclophosphamide. Semin Hematol. 2016; 53:90-97.

28. Duquesnoy R, Spellman S, Haagenson M, Wang T, Horowitz MM, Oudshoorn M. HLAMatchmaker-defined triplet matching is not associated with better survival rates of patients with class I HLA allele mismatched hematopoietic cell transplants from unrelated donors. Biol Blood Marrow Transplant. 2008; 14:1064-71.

29. Schetelig J, Bornhäuser M, Schmid C, Hertenstein B, Schwerdtfeger R, Martin H, Stelljes M, Hegenbart U, Schäfer-Eckart K, Füssel M, Wiedemann B, Thiede C, Kienast J, et al. Matched unrelated or matched sibling donors result in comparable survival after allogeneic stemcell transplantation in elderly patients with acute myeloid leukemia: a report from the cooperative German Transplant Study Group. J Clin Oncol. 2008; 26:5183-91.

30. Ruggeri L, Mancusi A, Capanni M, Urbani E, Carotti A, Aloisi T, Stern M, Pende D, Perruccio K, Burchielli E, Topini F, Bianchi E, Aversa F, et al. Donor natural killer cell allorecognition of missing self in haploidentical hematopoietic transplantation for acute myeloid leukemia: challenging its predictive value. Blood. 2007; 110:433-40.

31. Ruggeri L, Mancusi A, Burchielli E, Aversa F, Martelli MF, Velardi A. Natural killer cell alloreactivity and haploidentical hematopoietic transplantation. Cytotherapy. 2006; 8:554-58.

32. Huang XJ, Zhu HH, Chang YJ, Xu LP, Liu DH, Zhang XH, Jiang B, Jiang Q, Jiang H, Chen YH, Chen H, Han W, Liu KY, Wang Y. The superiority of haploidentical related stem cell transplantation over chemotherapy alone as postremission treatment for patients with intermediateor high-risk acute myeloid leukemia in first complete remission. Blood. 2012; 119:5584-90.

33. Ciurea SO, Zhang MJ, Bacigalupo AA, Bashey A, Appelbaum FR, Aljitawi OS, Armand P, Antin JH, Chen J, Devine SM, Fowler DH, Luznik L, Nakamura $\mathrm{R}$, et al. Haploidentical transplant with posttransplant cyclophosphamide vs matched unrelated donor transplant for acute myeloid leukemia. Blood. 2015; 126:1033-40.

34. Di Stasi A, Milton DR, Poon LM, Hamdi A, Rondon G, Chen J, Pingali SR, Konopleva M, Kongtim P, Alousi A, Qazilbash MH, Ahmed S, Bashir Q, et al. Similar transplantation outcomes for acute myeloid leukemia and myelodysplastic syndrome patients with haploidentical versus 10/10 human leukocyte antigen-matched unrelated and related donors. Biol Blood Marrow Transplant. 2014; 20:1975-81.

35. Yahng SA, Kim JH, Jeon YW, Yoon JH, Shin SH, Lee SE, Cho BS, Eom KS, Kim YJ, Lee S, Min CK, Cho SG, Kim DW, et al. A well-tolerated regimen of $800 \mathrm{cGy}$ TBI-fludarabine-busulfan-ATG for reliable engraftment after unmanipulated haploidentical peripheral blood stem cell transplantation in adult patients with acute myeloid leukemia. Biol Blood Marrow Transplant. 2015; 21:119-29.

36. Yahng SA, Jeon YW, Yoon JH, Shin SH, Lee SE, Cho BS, Eom KS, Kim YJ, Lee S, Min CK, Cho SG, Kim DW, Lee JW, et al. Negative Impact of Unidirectional Hostversus-Graft Killer Cell Immunoglobulin-like Receptor Ligand Mismatch on Transplantation Outcomes after Unmanipulated Haploidentical Peripheral Blood Stem Cell Transplantation for Acute Myeloid Leukemia. Biol Blood Marrow Transplant. 2015.

37. Weisdorf D, Spellman S, Haagenson M, Horowitz M, Lee S, Anasetti C, Setterholm M, Drexler R, Maiers M, King $\mathrm{R}$, Confer D, Klein J. Classification of HLA-matching for retrospective analysis of unrelated donor transplantation: revised definitions to predict survival. Biol Blood Marrow Transplant. 2008; 14:748-58.

38. Wang J, Ouyang J, Zhou R, Chen B, Yang Y. Autologous hematopoietic stem cell transplantation for acute myeloid leukemia in first complete remission: a meta-analysis of randomized trials. Acta Haematol. 2010; 124:61-71.

39. Vellenga E, van Putten W, Ossenkoppele GJ, Verdonck LF, Theobald M, Cornelissen JJ, Huijgens PC, Maertens J, Gratwohl A, Schaafsma R, Schanz U, Graux C, Schouten HC, et al. Autologous peripheral blood stem cell transplantation for acute myeloid leukemia. Blood. 2011; 118:6037-42.

40. Seshadri T, Keating A. Is there a role for autotransplants in AML in first remission? Biol Blood Marrow Transplant. 2009; 15:17-20.

41. Breems DA, Van Putten WL, Huijgens PC, Ossenkoppele GJ, Verhoef GE, Verdonck LF, Vellenga E, De Greef GE, Jacky E, Van der Lelie J, Boogaerts MA, Löwenberg B. Prognostic index for adult patients with acute myeloid leukemia in first relapse. J Clin Oncol. 2005; 23:1969-78.

42. Foran JM, Pavletic SZ, Logan BR, Agovi-Johnson MA, Pérez WS, Bolwell BJ, Bornhäuser M, Bredeson CN, Cairo MS, Camitta BM, Copelan EA, Dehn J, Gale RP, et al. Unrelated donor allogeneic transplantation after failure of autologous transplantation for acute myelogenous leukemia: a study from the center for international blood and marrow transplantation research. Biol Blood Marrow Transplant. 2013; 19:1102-08.

43. Rocha V, Labopin M, Sanz G, Arcese W, Schwerdtfeger R, Bosi A, Jacobsen N, Ruutu T, de Lima M, Finke J, Frassoni F, Gluckman E, Acute Leukemia Working Party of 
European Blood, et al. Transplants of umbilical-cord blood or bone marrow from unrelated donors in adults with acute leukemia. N Engl J Med. 2004; 351:2276-85.

44. Laughlin MJ, Eapen M, Rubinstein P, Wagner JE, Zhang MJ, Champlin RE, Stevens C, Barker JN, Gale RP, Lazarus HM, Marks DI, van Rood JJ, Scaradavou A, Horowitz MM. Outcomes after transplantation of cord blood or bone marrow from unrelated donors in adults with leukemia. $\mathrm{N}$ Engl J Med. 2004; 351:2265-75.

45. Ruggeri A, Labopin M, Sanz G, Piemontese S, Arcese W, Bacigalupo A, Blaise D, Bosi A, Huang H, Karakasis D, Koc Y, Michallet M, Picardi A, et al. Comparison of outcomes after unrelated cord blood and unmanipulated haploidentical stem cell transplantation in adults with acute leukemia. Leukemia. 2015; 29:1891-900.

46. Shaffer LG, Slovak ML, Campbell LJ, Krager ES. ISCN (2009). An international system for human cytogenetic nomenclature. Basel, Switzerland.

47. O'Donnell MR, Tallman MS, Abboud CN, Altman JK, Appelbaum FR, Arber DA, Attar E, Borate U, Coutre SE, Damon LE, Lancet J, Maness LJ, Marcucci G, et al. Acute myeloid leukemia, version 2.2013. J Natl Compr Canc Netw. 2013; 11:1047-55.

48. Kim HJ, Min WS, Eom KS, Park SJ, Park YH, Kim DW, Lee JW, Park CW, Kim CC. Autologous stem cell transplantation using modified TAM or combination of triple-alkylating agents conditioning regimens as one of the post-remission treatments in patients with adult acute myeloid leukemia in first complete remission. Bone Marrow Transplant. 2004; 34:215-20.

49. Przepiorka D, Weisdorf D, Martin P, Klingemann HG, Beatty P, Hows J, Thomas ED. 1994 Consensus Conference on Acute GVHD Grading. Bone Marrow Transplant. 1995; 15:825-28.
50. Filipovich AH, Weisdorf D, Pavletic S, Socie G, Wingard JR, Lee SJ, Martin P, Chien J, Przepiorka D, Couriel D, Cowen EW, Dinndorf P, Farrell A, et al. National Institutes of Health consensus development project on criteria for clinical trials in chronic graft-versus-host disease: I. Diagnosis and staging working group report. Biol Blood Marrow Transplant. 2005; 11:945-56.

51. Greinix HT, Loddenkemper C, Pavletic SZ, Holler E, Socié G, Lawitschka A, Halter J, Wolff D. Diagnosis and staging of chronic graft-versus-host disease in the clinical practice. Biol Blood Marrow Transplant. 2011; 17:167-75.

52. Choi SM, Lee DG, Choi JH, Yoo JH, Kim YJ, Park SH, Park SN, Min CK, Lee S, Kim HJ, Kim DW, Lee JW, Min WS, et al. Risk-adapted preemptive therapy for cytomegalovirus disease after allogeneic stem cell transplantation: a single-center experience in Korea. Int $\mathrm{J}$ Hematol. 2005; 81:69-74.

53. Choi SM, Lee DG, Lim J, Park SH, Choi JH, Yoo JH, Lee JW, Kim Y, Han K, Min WS, Shin WS, Kim CC. Comparison of quantitative cytomegalovirus real-time PCR in whole blood and pp65 antigenemia assay: clinical utility of CMV real-time PCR in hematopoietic stem cell transplant recipients. J Korean Med Sci. 2009; 24:571-78.

54. Gray RJ. A class of k-sample tests for comparing the cumulative incidence of a competing risk. Ann Stat. 1988; 16:1141-54. 